Сергій Богунов, кандидат технічних наук ORCID ID 0000-0002-4946-1604

Олег Мітягін, кандидат історичних наук ORCID ID 0000-0003-1941-3561 Національний університет оборони України імені Івана Черняховського

Ірина Казак, кандидат педагогічних наук Національний технічний університет України «Київський політехнічний інститут імені Ігоря Сікорського»

ORCID ID 0000-0001-9450-8312

\title{
СТАНОВЛЕННЯ ТА РОЗВИТОК ПЕДАГОГІЧНОЇ МАЙСТЕРНОСТІ ВИКЛАДАЧА ВИЩОГО ВІЙСЬКОВОГО НАВЧАЛЬНОГО ЗАКЛАДУ: ОСНОВНІ СТРУКТУРНІ СКЛАДОВІ
}

У статті розглянуто поняття «педагогічна майстерність» та визначені складові структури педагогічної майстерності викладача вищого віськового навчального закладу. Проведено аналіз особливостей складових педагогічної майстерності та важливості кожної з них для прочесу підготовки курсантів (слухачів) у вищих військових навчальних закладах.

Ключові слова: педагогічна майстерність; структура; виклада; вищий військовий навчальний заклад; прочес навчання; складові; навчання; педагогічна діяльність.

Постановка проблеми. Професія викладача закладу вищої освіти - одна iз найбільш творчих i складних професій, в яких поєднано науку та мистецтво. Ця професія споріднена 3 працею письменника (творчість у підготовці матеріалу), режисера та постановника (створення замислу і його реалізація), актора (в педагогічній діяльності інструментом є особистість викладача), педагога, психолога та науковця [1, с. 434].

Актуальнсть проблеми формування педагогічної майстерності викладача вищого військового навчального закладу, як вияву високого рівня педагогічної діяльності, зумовлена такими чинниками: 1) високою соціальною та військовою значущістю діяльності педагога у підготовці висококваліфікованих фахівців для Збройних Сил України, формуванні у них готовності до захисту територіальної цілісності, суверенітету нашої держави, національної свідомості та стійких морально-психологічних якостей; 2) реалізацією курсу на поглиблення партнерства 3 НАТО, необхідністю запровадження в системі військової освіти принципів i технологій у підготовці викладачів, притаманних військовим навчальним закладам країн членів НАТО; 3) досвідом, набутим у ході проведення антитерористичної операції (операції об'єднаних сил) на сході країни; 4) потребою залучення до викладацької діяльності учасників бойових дій, їх відповідної психологопедагогічної та методичної до підготовки. 
Аналіз останніх досліджень. Педагогічна майстерність тісно переплітається із поняттям "педагогічне мистецтво". Помилкою є бачити близькість цих понять лише у прямій ієрархічній залежності: педагогічне мистецтво - найвищий рівень прояву майстерності. Насправді зв'язок між ними більш діалектичний.

Українська енциклопедія дає таке визначення поняттю "мистецтво": "Мистецтво - одна із форм суспільної свідомості, складова частина духовної культури людства, специфічний рід практично-духовного освоєння світу. Мистецтво відносять до всіх форм практичної діяльності, коли вона здійснюється вміло, майстерно, уміло, вправно не лише в технологічному, але й в естетичному сенсі" [2, с. 172].

Мистецтво асоціюється, насамперед, з творчим проявом особистості. Воно грунтується на емоційній сфері і спрямоване на пробудження та формування емоційних, естетичних почуттів. Мистецтво завжди зорієнтоване на творення. К. Д. Ушинський з цього приводу писав: "Наука лише вивчає те, що існує або існувало, а мистецтво прагне творити те, чого ще немає, і перед ним у майбутньому майорить мета й ідеал його творчості" [2, с. 174]. Не можна забувати й того, що мистецтво "постає як реальний продуктивний спосіб пізнавально-перетворювального діяння індивіда у світі, спосіб самовияву індивідуального «Я». Усе це більшою чи меншою мірою треба враховувати при визначенні майстерності викладача вищого військового навчального закладу (ВВНЗ).

Педагогічна майстерність - це досконале, творче виконання педагогами своїх професійних функцій на рівні мистецтва, в результаті чого створюються оптимальні соціально-психологічні умови для становлення особистості педагога, забезпечення його інтелектуального та моральнодуховного розвитку [2, с. 174$]$.

Отже, педагогічну майстерність викладача можна розглядати як найвищий рівень педагогічної діяльності (якщо ми характеризуємо якість результату), як вияв творчої активності особистості педагога (характеризуємо психологічний механізм успішної діяльності). Коли ж ми прагнемо усвідомити витоки розвитку майстерності, зрозуміти шляхи професійного самовдосконалення, доцільно навести таке визначення цієї педагогічної категорії: педагогічна майстерність - це комплекс властивостей особистості, що забезпечує самоорганізацію високого рівня професійної діяльності на рефлексивній основі [3, с. 34]. У нашому дослідження саме таке визначення педагогічної майстерності приймемо за основу. Водночас, аналіз психолого-педагогічної літератури свідчить про те, що науковці не дійшли єдиних піжходів щодо складових педагогічної майстерності.

Н.В. Кузьміна, М.В. Кухарев визначають такі складові педагогічної майстерності: гуманістичну спрямованість діяльності педагога; професійну компетентність; педагогічні здібності; педагогічну техніку [2, с. 174]. Всі ці елементи пов'язані між собою та мають здатність до саморозвитку. 
На думку авторів підручника (І.А. Зязюн, Л.В. Крамущенко, І.Ф.Кривонос, О.Г. Мирошник, В.А. Семиченко, Н.М. Тарасевич) педагогічна майстерність має такі складові: гуманістична спрямованість діяльності викладача, його професійна компетентність, педагогічні здібності і педагогічна техніка [3, с. 35]. Усі складники педагогічної майстерності взаємопов'язані, їм властивий саморозвиток, а не лише зростання під виливом зовнішніх чинників.

B.M. Нагаєв вважає, що педагогічна майстерність має таку структуру: морально-духовні якості, професійні знання, соціально- педагогічні якості, психолого-педагогічні уміння, педагогічна технікау [2, с. 175].

Метою статті $\epsilon$ визначення сутності та структури педагогічної майстерності викладача в процесі його становлення та розвитку у вищому військовому навчальному закладі.

Метод дослідження аналіз психолого-педагогічної літератури щодо визначення сутності поняття "педагогічна майстерність", складових структури педагогічної майстерності викладача ВВНЗ і їх особливостей.

Виклад основного матеріалу. Професійна педагогічна діяльність викладача може розглядатися як цілісна динамічна система, яка містить п'ять структурних елементів: суб'єкт педагогічного впливу, суб'єкт навчання, предмет їх спільної діяльності, цілі навчання, засоби педагогічної комунікації. Ці компоненти складають систему, бо ні один 3 них не може бути замінений іншим або їх сукупністю. Специфіка педагогічної майстерності в сучасних умовах навчання у ВВНЗ полягає в тому, що вона має певну структуру. Науковою новизною даного дослідження $є$ визначення структури педагогічної майстерності та особливостей іiі складових, критеріїв і рівнів оволодіння педагогічною майстерністю викладачем ВВНЗ.

Педагогічна майстерність, якою має оволодіти викладач ВВНЗ включає низку структурних складових: морально-духовні якості, професійні знання, сочіально-педагогічні якості, психолого-педагогічні уміння, педагогічну техніку. Розглянемо особливості цих складових педагогічної майстерності викладача.

Першою складовою у структурі педагогічної майстерності розглянемо морально-духовні якості. Великий чеський педагог Я. А. Коменський на основі аналізу надбань народів Європи в галузі освіти здійснив глибоке наукове обгрунтування дидактичних i організаційних засад навчання підростаючого покоління. Це започаткувало дидактично-освітню революцію у світі. Але діяльність освітніх закладів зосереджувалася в основному навколо проблеми оволодіння тими, хто навчається, певною сумою знань, умінь i навичок 3 урахуванням рівня розвитку науки та соціальноекономічних потреб. Питання виховання молоді, формування в особистості високих морально-духовних якостей залишалися поза увагою педагогів. Панувала навіть думка, що участь молодої людини в освітньому процесі автоматично забезпечує її виховання. 
Усвідомлюючи інформаційну й технократичну загрозу, суспільство зобов'язане на новому етапі соціально-економічного розвитку рішуче перейти до наукового обгрунтування та здійснення освітньо-виховної революції, яка б поставила виховання людини на одному рівні з навчанням. Цей процес складний, тривалий, пов'язаний із руйнуванням усталених стереотипів, але неминучий. Провідну роль за такого підходу до організації освітньо-виховного процесу має відігравати педагог.

Важливою складовою педагогічної діяльності $є$ iï гуманістична спрямованість. У центрі уваги освітнього процесу має бути курсант (слухач). Викладач повинен виявляти глибоку повагу до його особистості, шанувати, оберігати від негативних впливів, створювати оптимальні умови для всебічного розвитку. За приклад тут може правити педагогічна діяльність B.О. Сухомлинського, у центрі уваги якого завжди мала місце повага до вихованців і водночас - вимогливість до них.

Важливим чинником у системі морально-духовних якостей особистості викладача $є$ рівень сформованості почуття наиіональної гідності. Це почуття розкривається передусім через такі риси: любов до свого народу, Батьківщини; повага до Конституції та законів України, державних символів; досконале володіння державною мовою, турбота про піднесення іiі престижу й функціонування в усіх сферах суспільного життя; шанобливе ставлення до батьків, свого роду, традицій та історії рідного народу, усвідомлення своєї належності до нього; повага до культури, традицій та звичаїв народностей, що проживають на теренах України. Курсанти (слухачі) чутливі до того, наскільки у їхніх викладачів сформоване почуття національної гідності. Ця якість - своєрідний тест, що визначає вплив викладача на тих, хто навчається.

Чільне місце в системі морально-духовних цінностей викладача вищої школи посідають життєві ідеали. Це важливо ще й тому, що вік, зокрема, курсанта, є періодом його становлення, роздумів про майбутню професійну діяльність. Яскраво виражені життєві ідеали досвідченого викладача завжди знайдуть відгук у свідомості курсантів (слухачів). Адже ідеал - це категорія етики, яка містить у собі довершені моральні якості; уособлення найбільш цінного й величного в людині, що дає змогу майбутнім військовим фахівцям успішно вдосконалюватися. Прояв викладачем своїх життєвих ідеалів особливо важливий у наш час, коли у зв'язку з історичними змінами, подіями на сході нашої країни, соціальними катаклізмами зникли звичні ідеали, що, здебільшого, мали фальшивий характер, а нові, справжні ще не утвердилися повною мірою. Залишати тих, хто навчається, без істинних взірців - означає підштовхувати їх до стану розчарування, пасивності, духовної деградації.

До зовнішніх чинників, що забезпечують зміцнення й підкріплення педагогічної майстерності викладача, належать совісність (сумління), честь, справедливість $i$ об'єктивність. Курсанти (слухачі) особливо чутливо ставляться до цих якостей педагога й боляче реагують на їх відсутність, недостатню виразність. Сумління як категорія етики визначається здатністю 
людини контролювати власну діяльність, давати об'єктивну оцінку своїм діям. Почуття честі характеризує особистість 3 погляду пї готовності підтримувати й обстоювати гідність, репутацію - особисту чи колективну, членом якого вона $є$. Совісність і чесність виконують регулятивну функцію в життедіяльності людини, ïi спілкуванні 3 іншими людьми. А оскільки викладачеві ВВНЗ доводиться повсякденно спілкуватися 3 курсантами (слухачами), які ще не мають достатнього життєвого досвіду, весь час перебувати на "сцені педагогічного олімпу", то вміння саморегуляції та регуляції, оцінювання своєї поведінки йому конче необхідні. До того ж викладач має дбати про підтримання не лише власної гідності, а й репутації педагогічного колективу.

Другою складовою педагогічної майстерності $є$ професійні знання. Курсанти (слухачі) високо цінують викладача, який володіє глибокими знаннями зі свого фаху, виявляє обізнаність зі спорідненими дисциплінами, відзначається науковою ерудицією. Без цього немає майстерності педагога. Це вимагає від нього щоденної наполегливої праці над собою, накопичення і систематизації нових наукових знань. На цьому шляху кожного викладача підстерігає чимало труднощів: брак часу, великий обсяг інформації, підготовка до занять, специфічність військово-освітньої діяльності тощол. Зрештою, й економічні чинники не завжди дають можливість бажане наблизити до реального. Добрим помічником викладачеві у цій справі може стати використання комп'ютерної техніки, застосування інформаційних технологій.

Лише оволодіння базовими знаннями з психології та педагогіки вищої школи, фахових методик забезпечить надійний грунт для реалізації своїх можливостей і полегшить шлях до педагогічної майстерності.

Третьою складовою структури педагогічної майстерності викладача ВВНЗ є наявність у нього необхідних соціально-педагогічних якостей. При цьому варто зважати на те, що соціально-педагогічні якості - це результат виховного впливу на особистість сім’і, соціуму, військового середовища, освітнього закладу та ін. Вони частково входять до змісту професіограми військового педагога. Професіограма - це перелік якостей особистості, необхідних для успішного виконання функціональних обов'язків 3 конкретного фаху. Професіограми не є сталими моделями. Змінюються умови праці, оновлюються технології навчання - змінюються й вимоги до якостей викладача.

Серед якостей особистості викладача, визначальних у процесі становлення педагогічної культури, майстерності й професіоналізму, особливо важливим є педагогічний такт (лат. tactus - дотик, відчуття). Тактовність є свідченням сформованості педагогічної культури викладача, передумовою вияву в його душі "вільних валенсій", які притягують до нього курсантів (слухачів). Це чутливий інструмент попередження міжособистісних конфліктів, яскравий показник педагогічної майстерності. Оскільки навіть пересічна людина, яка сповідує засади загальнолюдської та 
професійної культури, повинна володіти педагогічним тактом, то викладач ВВНЗ в процесі спілкування 3 курсантами(слухачами), розв'язуючи перманентні педагогічні завдання, має виявляти довершені зразки тактовності, будувати свої стосунки 3 тими, хто навчається, на суб'єктсуб'єктних засадах.

Чотвертою важливою складовою у структурі педагогічної майстерності викладача ВВНЗ є комплекс психолого-педагогічних умінь: конструктивних, комунікативних, дидактичних, перцептивних, сугестивних, пізнавальних, прикладних, організаторських, психотехнічних та ін. Більшість названих умінь, грунтуючись на комплексі соціально-педагогічних якостей, формуються в процесі навчання у ВВНЗ, служби у військах, навчання на курсах підвищення кваліфікації, а також у ході безпосередньої педагогічної діяльності. Цей процес досить тривалий, вимагає від особистості викладача наполегливої цілеспрямованої роботи над собою.

Розглянемо сутність і зміст основних психолого-педагогічних умінь викладача ВВНЗ.

Конструктивні вміння передбачають: добір доцільних форм і видів діяльності; добір дієвих методів і засобів виховного впливу; планування перспективних етапів у керівництві колективом курсантів (слухачів); здійснення індивідуально орієнтованого підходу до майбутніх військових фахівців.

Комунікативні вміння покликані забезпечити доцільність стосунків із суб'єктами освітнього процесу, зокрема, встановлювати педагогічно вмотивовані контакти 3 курсантами (слухачами), своїми колегами, викладачами суміжних навчальних дисциплінтощо.

Організаторські вміння уможливлюють розв'язання певних педагогічних завдань: організовувати й керувати колективами курсантів (слухачів), створювати оптимальні умови для їх розвитку; забезпечувати педагогічно ефективну діяльність навчальних колективів; організовувати роботу з курсантами (слухачами) у позанавчальний час (самостійна робота, консультації, підготовка до екзаменів тощо).

Дидактичні вміння виявляються в тому, щоб пояснювати курсантам (слухачам) навчальний матеріал на доступному для них рівні сприймання; керувати їх самостійною навчально-пізнавальною діяльністю, сприяти розвитку їхніх пізнавальних інтересів, інтелектуальних можливостей, формувати й розвивати у тих, хто навчається, дієві мотиви навчальної праці; навчати оволодінню ефективними й раціональними методами самостійної пізнавальної діяльності.

Перцептивні вміння (лат. perceptio - сприймання, пізнання, чуттєве сприйняття, розуміння й оцінка людьми соціальних об'єктів - інших людей, самих себе, груп та ін.) охоплюють: здатність проникати у внутрішній світ курсантів (слухачів); розуміти їхній психічний стан; спостережливість, що дає змогу розуміти реальний психічний стан того, хто навчається, в конкретній ситуації. 
Сугестивні вміння (лат. suggestio - навіюю) становлять безпосередній емоційно-вольовий вплив педагога на тих, хто навчається, з метою створення в них певного психічного стану, спонукання їх до конкретних дій.

Пізнавальні вміння включають: вивчення індивідуальних особливостей фізичного, психічного й соціального розвитку курсантів (слухачів); оволодіння новою науковою інформацією, раціональне використання іiі в науково-педагогічній роботі; вивчення кращого національного та закорлрнного педагогічного досвіду, в першу чергу, військових навчальних закладів провідних країн НАТО, та його творче використання у власній викладацькій діяльності.

Прикладні вміння грунтуються: на володінні технічними засобами навчання, тренажерною та комп'ютерною технікою; інтерактивними інформаційними технологіями тощо.

Уміння в галузі психотехніки передбачають свідоме й доцільне використання надбань психології у сфері навчання, виховання, розвитку, психологічної підготовки курсантів (слухачів) до майбутньої військової служби.

Достатня сформованість у викладача ВВНЗ зазначених вище вмінь $\epsilon$ необхідною умовою розв'язання різноманітних педагогічних, військовопрофесійних завдань на рівні педагогічної майстерності.

П’ятою складовою у структурі педагогічної майстерності є педагогічна техніка.

Педагогічна техніка - це сукупність раціональних засобів, умінь та особливостей поведінки педагога, спрямованих на ефективну реалізацію обраних ним методів і прийомів навчально-виховної роботи 3 окремим індивідом чи колективом відповідно до поставленої мети навчання та виховання 3 урахуванням конкретних об'єктивних і суб' єктивних умов $[2,174]$.

Критеріями педагогічної майстерності викладача ВВНЗ є: доиільність (за спрямованістю), продуктивність (за результатами), діалогічність (за характером стосунків 3 студентами), оптимальність у виборі засобів, mворчість (за змістом діяльності). Автори підручника [3, с. 34] визначають такі рівні оволодіння педагогічною майстерністю: елементарний, базовий, досконалий, творчий.

Процес оволодіння педагогічною майстерністю має певні особливості:

- не можна вдосконалити свою педагогічну майстерність, не займаючись постійним вивченням власної методики, i навпаки, не можна вивчати методику, не вдосконалюючи їі;

- не можна вдосконалити свою майстерність, не використовуючи національний і закордонний досвід, досвід колег;

- оцінка власної методики i методик викладачів національних i зарубіжних військових навчальних закладів можлива лише у практичній діяльності щляхом апробації; 
- вдосконалення та самовдосконалення викладача ВВНЗ - процес творчий і неперервний.

Висновки та перспективи подальших досліджень. У статті показана актуальність досліджуваної проблеми в контексті необхідності вивчення та узагальнення досвіду становлення та розвитку педагогічної майстерності викладачів військових навчальних закладів провідних країн НАТО. Розглянуті сутність "педагогічної майстерності", iї структура та особливості. Під педагогічною майстерністю розуміється комплекс властивостей особистості, що забезпечує самоорганізацію високого рівня професійної діяльності на рефлексивній основі. Визначена така структура педагогічної майстерності викладача ВВНЗ: морально-духовні якості, професійні знання, соціально-педагогічні якості, психолого-педагогічні уміння, педагогічна техніка. Виявлені критерії педагогічної майстерності (доцільність (за спрямованістю), продуктивність (за результатами), діалогічність (за характером стосунків 3 курсантами, слухачами), оптимальність у виборі засобів, творчість (за змістом діяльності), наведені рівні оволодіння педагогічною майстерністю викладачем ВВНЗ.

Перспективами подальших досліджень є такі напрями: організаційнометодичні основи підготовки та підвищення педагогічної кваліфікації викладачів військових навчальних закладів провідних країн НАТО; використання інноваційних педагогічних технологій в системі підготовки військових фахівців у ВВНЗ України.

\section{ЛІТЕРАТУРА}

1. Зязюн I. А. Педагогічна майстерність: Хрестоматія / І. А. Зязюн, Н. Г. Базилевич, Т.Г. Дмитренко та ін. - К.: Вища шк., 2006. — 606 с.

2. Нагаєв В. М. Методика викладання у вищій школі / В.М. Нагаєв. - Харк. нац. аграрн. ун-т ім. В.В. Докучаєва: [навч. посіб.] — К.: ЧП.- 2007. - 217 с.

3. Педагогічна майстерність: підручник / І.А. Зязюн, Л.В. Крамущенко, І.Ф. Кривонос та ін.; за ред.. І.А. Зязюна. - 2-е вид., допов. і переробл. - Вища шк, 2004.- 422 с.

\section{REFERENCES}

1. Zyazyun, I.A., Bazilevich, N.G.,. Dmitrenko, T.G. (2006). Pedagogichna majsternist: Hrestomatiya [ Pedagogical skill: Reading literature ]. K.: Visha shk., 606 (in Ukrainian).

2. Nagayev, V. M. (2007). Metodika vikladannya u vishij shkoli [Teaching method in high school ]. Hark. nac. agrarn. un-t im. V.V. Dokuchayeva: [navch. posib.]. K.: ChP, 217 (in Ukrainian).

3. Zyazyun, I.A. Kramushenko, L.V. Krivonos, I.F. ta in.; za red.. I.A. Zyazyuna (2004). Pedagogichna majsternist: pidruchnik, 2-e vid., dopov. i pererobl [ Pedagogical skill: textbook]. K.: Visha shk, 422 (in Ukrainian). 


\section{РЕЗЮМЕ}

Богунов Сергей, кандидат технических наук,

Олег Митягин, кандидат исторических наук Национальный университет обороны Украины имени Ивана Черняховского

Казак Ирина, кандидат педагогических наук Национальный технический университет Украины «Киевский политехнический институт имени Игоря Сикорского»

\section{Становление и развитие педагогического мастерства преподавателя высшего военного учебного заведения: основные структурные составляющие}

В статье рассмотрено понятие «педагогическое мастерство» и определень составляющие структуры педагогического мастерства преподавателя высшего военного учебного заведения. Проведен анализ особенностей составляющих педагогического мастерства и важности каждой из них для прочесса подготовки курсантов (слушателей) в высших военных учебных заведениях.

Ключевые слова: педагогическое мастерство; структура.; преподаватель; высшее военное учебное заведение; процесс обучения; составляющие; обучение; педагогическая деятельность.

\section{SUMMARY}

Sergej Bogunov, candidate of technical sciences,

Oleh Mitiahin,

candidate of Historical Science

National Defence University of Ukraine named after Ivan Chernyakhovskyi

Irina Kazak, candidate of pedagogical sciences

National Technical University of Ukraine «Kiev Polytechnic Institute named after Igor Sikorskyi»

\section{Peculiarities of the structure of pedagogical mastery of the teacher of the higher educational institution}

Introduction. In modern times, the problem of the formation of pedagogical skill as a manifestation of a high level of pedagogical activity is topical, it has a high social significance and occupies one of the central places among the components of pedagogical activity in the training of highly qualified specialists for the society, the formation of national consciousness and spiritual culture of Ukrainian students.

Purpouse. Definition of the essence, structure and features of the teacher's higher education institution's pedagogical skills.

Method. Analysis of educational, psychological and pedagogical literature on the definition of the essence of the concept of "pedagogical skill" that make up the structure of pedagogical mastery of a teacher of a higher educational institution and their characteristics.

Results. As a result of the analysis of scientific, psychological and pedagogical literature, the article reveals the components of pedagogical skill: moral and spiritual qualities, 
professional knowledge, social and pedagogical qualities, psychological and pedagogical skills, pedagogical techniques.

Practical value. As a result of the study of the concept of "pedagogical skill", the constituent structures and their characteristics, criteria and levels of pedagogical mastering of the teacher of the higher academic institution are determined, on the basis of which it is possible to provide training of highly qualified specialists for various sectors of society.

Originality. The scientific novelty of this study is the definition of the structure of pedagogical skills and the characteristics of its components, criteria and levels of mastery of pedagogical skill by a teacher of a higher educational institution.

Conclusion. In the article the essence of "pedagogical skill", its structure and features of the components of pedagogical skill are considered. By pedagogical skill we will understand a set of personality traits that ensures self-organization of a high level of professional activity on a reflexive basis. Pedagogical mastery has the following structure: moral and spiritual qualities, professional knowledge, social and pedagogical qualities, psychological and pedagogical skills, pedagogical technique. The criteria of pedagogical skill (expediency (direction), productivity (by results), dialogicity (by the nature of relations with students), optimality in the choice of means, creativity (on the content of activity) were also revealed and characteristics of these criteria were given at the risch levels of pedagogical skill elementary, basic, perfect, creative).

Further research will be devoted to the teacher's use of the specifics of pedagogical skill in specific situations in the process of teaching and educating students in a university.

Key words: pedagogical skill; structure; teacher; higher educational institution; the process of teaching; components; training; pedagogical activity.

Ключевые слова: педагогическое мастерство; структура.; преподаватель; высшее военное учебное заведение; прочесс обучения; составляющие; обучение; педагогическая деятельность. 